\title{
Women Empowerment through Self-Help Groups: A Study in Jalukie Block, Peren District of Nagaland
}

\author{
Isapeule ${ }^{1}$, J. Longkumer ${ }^{2}$ and T. Longchar ${ }^{3 *}$
}

${ }^{182}$ Dept. of Agricultural Extension, ${ }^{3}$ Dept. of Agriculture, Government of Nagaland, Medziphema, Nagaland (797 106), India

\section{Corresponding Author}

T. Longchar

e-mail: tiyajung@gmail.com

\author{
Article History \\ Article ID: AR1852a \\ Received in 05 ${ }^{\text {th }}$ December, 2017 \\ Received in revised form $18^{\text {th }}$ February, 2018 \\ Accepted in final form $27^{\text {th }}$ April, 2018
}

\begin{abstract}
SHGs were started in Nagaland during 1999-2000 under the centrally sponsored scheme SGSY (Mishra and Langwangbe, 2014). Besides SGSY, the state Rural Development Department, Department of Women Development, North East Rural Livelihoods Project (NERLP), and Nagaland Empowerment of People through Economic Development (NEPeD) has also played a great role in promoting SHGs in the state. NGOs like Rongmai Baptist Association Nagaland (RBAN), Prodigals' Home, Development Association of Nagaland (DAN) and Agency for Integral Development Action (AIDA) played a significant role in promotion of women empowerment through formation of SHGs in various areas of the state. The study was undertaken in Jalukie block, Peren district of Nagaland. Findings revealed that higher incidence was observed from SHG members in the sample consisted of young aged women up to 35 years (47.50\%), educational qualification up to secondary standard (82.50\%), nuclear family type (85.00\%), family size of 3-5 members $(43.33 \%)$, business occupation (58.33\%), annual average income of above ₹ $26,784-₹ 49,316 /-(58.33 \%)$, high level of self-confidence (67.50\%), and having a family support to great extent (63.33\%). Observations depicted that the SHG members were involved in small scale business enterprises such as piggery, weaving, poultry, grocery shops and vegetables. The analysis showed that $65.83 \%$ of SHG members were empowered moderately, while $17.50 \%$ were empowered at low level and about $16.67 \%$ were highly empowered. The study showed that Self Help Groups can contribute towards empowerment of women and can play a very important role in bringing about positive changes in their lives.
\end{abstract}

Keywords: Self Help Groups, women, empowerment, annual income, role

\section{Introduction}

In India, Self Help Groups (SHGs) were started by Mysore Resettlement and Development Agency (MYRADA), a Karnataka based NGO in 1985 to enable the members secure credit collectively for activities which could provide them economically gainful employment. In 1989, NABARD launched an action research project in which grants were provided to NGOs. Later the SHG-Bank Linkage Programme was launched in 1992 (Fernandez, 2007). During 2014-15 about 2.68 lakh new SHGs were added in the domain of SHG and increased to 76.97 lakh as on 31 ${ }^{\text {st }}$ March 2015 (NABARD SMFI, 2014-15).

In the Northeast region, the SHG movement started in late 1990s for Assam and early 2000 for other states. The region has seen rapid growth of SHGs with the support of microfinance from NABARD, a stakeholder for provision of microfinance in the region and India as well. The total number of SHGs with savings in banks was 3,33,981 with a savings amount of ₹ 13,021.87 lakhs in the NE region during 2014-15 (NABARD SMFI, 2014-15). In the North-East Region, SHGs are promoted by government programmes like SHG-BLP (an initiation of NABARD) and Swarnajayanti Gram Swarozgar Yojana (SGSY). Besides, the programme of the North Eastern Council called the North Eastern Region Community Resource Management Project (NERCORMP) promoted SHGs among six hill districts in three states of Manipur, Assam and Meghalaya. The Northeast region has a number and variety of Self Help Promoting Agencies (SHPAs). However, NGOs were in the forefront of SHGs promotion in the region.

SHGs were started in Nagaland during 1999-2000 under the centrally sponsored scheme SGSY (Mishra and Langwangbe, 2014). Besides SGSY, the state Rural Development Department, Department of Women Resources Development, North East Rural Livelihoods Project (NERLP), and Nagaland Empowerment of People through Economic Development (NEPeD) has also played a great role in promoting SHGs in the state. NGOs like Rongmai Baptist Association Nagaland (RBAN), Prodigals' Home, Development Association of Nagaland (DAN) and Agency for Integral Development Action (AIDA) played a significant role in promotion of women empowerment through formation of SHGs in various areas of 
the state. Also the Eleutheros Christian Society in Tuensang district has contributed immensely to the Eastern society with the inception of EDOU meaning "farming together", a shared banking system within the SHGs and initiated on March $10^{\text {th }}$ 2003. The unique and dynamic feature of EDOU is that the interest goes back to the group as a dividend after every three years. There are 2880 number of SHGs with saving bank accounts with a total of ₹ 273.01 lakhs during 2014-15 as savings in Nagaland (NABARD SMFI, 2014-15). There are a total of 24 numbers of major banking companies operating with 146 branches spread across the state (Langwangbe, 2014).

The SHGs have played an important role in the uplift of women in various spheres and empowerment has been the most important hall mark. Empowerment can be viewed as means of creating a social environment in which one can make decisions (Hashemi et al., 1996). The relevance of SHGs as powerful instruments of social, political and economic empowerment of women has also been unanimously accepted in many studies (Ramachandran and Balakrishnan, 2008; Swain and Wallentin, 2012). Empowerment of women is critical not only for their own welfare but also for the development of the country. Young (1993) said "Empowerment enables women to take control of their own lives, set their own agenda, organize to keep each other and make demands on the state for support on the society itself for change."

\section{Materials and Methods}

The present study was undertaken in Jalukie block under Peren district of Nagaland state from December 2016 to February, 2017. Descriptive Research Design was adopted for this study for studying the socio-economic characteristics of women Self-Help Groups and their empowerment. Multistage sampling procedure was followed for selecting the respondents. Data was collected from 30 Self Help Groups spread across six villages through personal interview method. A total of 120 respondents were selected for the study. Independent variables such as age, education, family type, family size, occupation, annual income, self confidence and family support were measured with the help of frequency, percentage, mean and standard deviation. The dependent variable i.e. Women empowerment covered three dimensions-social, economic and political. Correlation analysis was used to establish the relationship between independent variables and dependent variable (Table 10). The list of selected variables and their measurements are presented in Tables 1-9.

In the present investigation, annual income is referred to as the monetary income received by the respondent's family from all sources including income from agriculture and other subsidiary activities like weaving and regular paid government and non-government services and operationally measured in terms of actual annual income expressed in rupees. Here family refers to the degree to which a respondent is supported by her husband and her family members-financially, physically and mentally. Self confidence, on the other hand, refers to participation in any group activities which would bring a higher level of confidence in their behavior and outlook. Schedule was developed and scoring was on five questions based on self confidence.

\section{Results and Discussion}

\subsection{Socio-economic status of the respondents}

The socio-economic status of the sample respondents is given from Table 1 to Table 8 . Higher incidence was observed from the following- young aged women up to 35 years $(47.50 \%)$, educational qualification up to secondary standard (82.50\%), nuclear family type (85.00\%), family size of 3-5 members (43.33\%), business occupation (58.33\%), annual average income of above ₹ $26,784-49,316 /-(58.33 \%)$, high level of self-confidence (67.50\%), and having a family support to great extent (63.33\%).

\subsection{Activities undertaken by SHGS}

Observation of the Table 9 showed that SHG members were involved in income generating activities such as piggery $(33.33 \%)$, poultry rearing $(1.67 \%)$; business activities like

Table 1: Categorization of respondents according to their age $n=120$

\begin{tabular}{lcc}
\hline Category & Frequency & Percentage (\%) \\
\hline Young (up to 35 years) & 57 & 47.50 \\
Middle (35-50 years) & 48 & 40.00 \\
Old (Above 50 years) & 15 & 12.50 \\
Total & 120 & 100 \\
\hline
\end{tabular}

Table 2: Categorization of respondents based on their level of education $n=120$

\begin{tabular}{lcc}
\hline Category & Frequency & Percentage (\%) \\
\hline Able to read/write & 3 & 2.50 \\
Up to primary standard & 16 & 13.30 \\
Up to secondary standard & 99 & 82.40 \\
Above secondary & 2 & 1.70 \\
Total & 120 & 100 \\
\hline
\end{tabular}

Table 3: Categorization of respondents based on their family type $n=120$

\begin{tabular}{lcc}
\hline Category & Frequency & Percentage (\%) \\
\hline Nuclear & 102 & 85.00 \\
Joint & 18 & 15.00 \\
Total & 120 & 100 \\
\hline
\end{tabular}


selling vegetables $(14.17 \%)$ in nearby markets, opening petty shops (5.00\%); weaving traditional and non-traditional clothing $(15.00 \%)$ and other mixed activities like piggery and

Table 4: Categorization of respondents based on their family size $n=120$

\begin{tabular}{lcc}
\hline Category & Frequency & Percentage (\%) \\
\hline Small (3-5 family members) & 52 & 43.33 \\
Medium (5-7family members) & 49 & 40.83 \\
Big (More than 7 family & 19 & 15.83 \\
members) & & \\
Total & 120 & 100 \\
\hline
\end{tabular}

Table 5: Categorization of respondents based on their primary occupation $n=120$

\begin{tabular}{lcc}
\hline Category & Frequency & Percentage (\%) \\
\hline Agriculture & 44 & 36.67 \\
Business & 70 & 58.33 \\
Service & 6 & 5.00 \\
Total & 120 & 100 \\
\hline
\end{tabular}

Table 6: Categorization of respondents based on their annual income $\mathrm{n}=120$

\begin{tabular}{lcccc}
\hline Category & $\begin{array}{c}\text { Fre- } \\
\text { quency }\end{array}$ & $\begin{array}{c}\text { Percent- } \\
\text { age (\%) }\end{array}$ & Mean & SD \\
\hline Below ₹ 26,784 & 26 & 21.67 & ₹ & ₹ \\
₹ 26,784-₹ 49,316 & 70 & 58.33 & 30,050 & $11,265.62$ \\
Above ₹ 49,316 & 24 & 20.00 & & \\
Total & 120 & 100 & & \\
\hline
\end{tabular}

Table 7: Categorization of respondents based on their level of self confidence $n=120$

\begin{tabular}{lcccc}
\hline Category & $\begin{array}{c}\text { Fre- } \\
\text { quency }\end{array}$ & $\begin{array}{c}\text { Percent- } \\
\text { age (\%) }\end{array}$ & Mean & SD \\
\hline Low (Below 20.61) & 12 & 10.00 & 26.68 & 6.07 \\
High (20.16-32.75) & 81 & 67.50 & & \\
Very high (Above 32.75) & 27 & 22.50 & & \\
Total & 120 & 100 & & \\
\hline
\end{tabular}

Table 8: Categorization of respondents based on their extent of family $n=120$

\begin{tabular}{lcc}
\hline Category & Frequency & Percentage (\%) \\
\hline Not at all & 3 & 2.50 \\
To some extent & 41 & 34.17 \\
To great extent & 76 & 63.33 \\
Total & 120 & 100 \\
\hline
\end{tabular}

Table 9: Categorization of respondents based on their activities

\begin{tabular}{lccc}
\hline Category & Frequency & $\begin{array}{c}\text { Percentage } \\
(\%)\end{array}$ & $\begin{array}{c}\text { AAl } \\
(₹)\end{array}$ \\
\hline Piggery and Duckery & 1 & 0.83 & 30,000 \\
Poultry & 2 & 1.67 & 36,000 \\
Petty shops & 6 & 5.00 & 35,000 \\
Piggery and selling & 8 & 6.67 & 33,125 \\
vegetables & & & \\
Selling vegetables & 17 & 14.17 & 41,353 \\
Weaving & 18 & 15.00 & 34,389 \\
Piggery and weaving & 28 & 23.33 & 41,036 \\
Piggery & 40 & 33.33 & 37,950 \\
\hline
\end{tabular}

AAl: Average annual income ( $₹$ in thousands)

weaving (23.33\%), piggery and selling vegetables (6.67\%) and piggery and duckery $(0.83 \%)$. It was found out that these activities were not performed in groups but as individuals. The groups availed loans by the federations and they divided the money among themselves, each to carry out the income generating activities of her choice. It was reported that their activities were limited to less variety because of the limited amount of loans the groups were availed by the banks.

3.4. Relationship of independent variables with dependent variable empowerment

Table 10 revealed that Educational qualification, Family type and Mass media exposure had a positive and significant association with the Economic Empowerment (at 5\% level of significance) and Family size had significant correlation with Economic Empowerment (at 1\% level of significance). The

Table 10: Relationship of independent variables with dependent variable empowerment

\begin{tabular}{lccc}
\hline Independent variables & $\mathrm{EE}$ & $\mathrm{SE}$ & $\mathrm{PE}$ \\
\hline Age & $-0.2699^{\mathrm{NS}}$ & $-0.1396^{\mathrm{NS}}$ & $0.1031^{\mathrm{NS}}$ \\
Educational qualification & $0.1859^{*}$ & $0.1723^{*}$ & $-0.0527^{\mathrm{NS}}$ \\
Family type & $0.1810^{*}$ & $0.2001^{*}$ & $-0.1218^{\mathrm{NS}}$ \\
Family size & $0.3049^{* *}$ & $0.0133^{\mathrm{NS}}$ & $-0.1325^{\mathrm{NS}}$ \\
Primary occupation & $0.1108^{\mathrm{NS}}$ & $0.0418^{\mathrm{NS}}$ & $0.0749^{\mathrm{NS}}$ \\
Annual income & $-0.0488^{\mathrm{NS}}$ & $-0.0322^{\mathrm{NS}}$ & $0.0265^{\mathrm{NS}}$ \\
Mass media exposure & $0.2299^{*}$ & $0.0384^{\mathrm{NS}}$ & $-0.1170^{\mathrm{NS}}$ \\
Self confidence & $0.0531^{\mathrm{NS}}$ & $0.1489^{\mathrm{NS}}$ & $0.0597^{\mathrm{NS}}$ \\
Family support & $0.0087^{\mathrm{NS}}$ & $-0.1218^{\mathrm{NS}}$ & $0.1408^{\mathrm{NS}}$ \\
\hline
\end{tabular}

EE: Economic empowerment; SE: Social empowerment; PE: Political empowerment; * : Significant at $(p=0.05)$ level of significance; ${ }^{* *}$ : Significant at $(p=0.01)$ level of significance; NS: Non-significant at $(p=0.05)$ level of significance 
Educational qualification and Family type were also positively and significantly associated with Social Empowerment at 5\% level of significance.

\subsection{Empowerment of women members through SHGs}

Three dimensions of empowerment (i.e. Economic, Social and Political) were measured by developing empowerment index (Table 11). The Economic Empowerment indicated that the members could have access to easy credit through joining SHGs, increase in income level through small scale economic activities, better expenditure structure at home, better saving status, better repayment status of loan, ability to make small purchases for domestic uses, economic contribution to the household through personal earning and more control over finance at home. However, they were not able to make large purchases with their small amount of income and also they did not learn better business practices and management as reported by them. With regard to Social Empowerment, the members had a more assertive role in upbringing of children

\begin{tabular}{|c|c|c|c|}
\hline Index & Category & $\begin{array}{c}\text { Fre- } \\
\text { quency }\end{array}$ & $\begin{array}{l}\text { Percent- } \\
\text { age (\%) }\end{array}$ \\
\hline \multirow{3}{*}{$\begin{array}{l}\text { Economic } \\
\text { empower- } \\
\text { ment }\end{array}$} & Low (0 - 16.72) & 14 & 11.67 \\
\hline & Medium (16.72-22.38) & 106 & 88.33 \\
\hline & High (Above 22.38) & 0 & 0.00 \\
\hline \multirow{3}{*}{$\begin{array}{l}\text { Social em- } \\
\text { powerment }\end{array}$} & Low (0-4.82) & 27 & 22.50 \\
\hline & Medium (4.82-6.64) & 54 & 45.00 \\
\hline & High (Above 6.64) & 39 & 32.50 \\
\hline \multirow{3}{*}{$\begin{array}{l}\text { Political } \\
\text { empower- } \\
\text { ment }\end{array}$} & Low (0-3.87) & 19 & 15.83 \\
\hline & Medium (3.87-5.51) & 101 & 84.17 \\
\hline & High (Above 5.51) & 0 & 0.00 \\
\hline
\end{tabular}

and recreation in the family and a lower score in taking major decisions at home and in the society. In the political domain it was it was observed that, even though women were very active in political participation, there was strict restriction for involvement in taking major decisions and major political bodies. From this, it can be inferred that women maybe actively involved in the political arena behind the scenes but cannot participate in the actual decision making processes. Thus, this contradiction has resulted in the projection of a moderate level of political empowerment showing a high percentage of $84.17 \%$.

\section{Conclusion}

Majority (83.33\%) members were empowered up to a medium level of economic empowerment while in the category of social empowerment it was found that $45.0 \%$ members had medium level of social empowerment, followed by $32.5 \%$ members scoring high level. In the category of political empowerment, it was found that majority (84.17\%) showed medium level of political empowerment.

Indeed, the study proved that the respondents were empowered in various capacities through the SHGs.

\section{References}

Census, 2011. Interesting and fun facts.Directorate of Census Operations, Bayavii Hill, High School Road, Kohima, Nagaland, 9.

Fernandez, A.P., 2007. History and spread of the self-help affinity group movement in India: The role played by IFAD, 9-14.

Hashemi, S.M., Schuler, S.R. Riley, A.P., 1996. Rural Credit Programs and Women's Empowerment in Bangladesh. World Development 24(4), 635-653.

Langwangbe, K.T., 2014. Self Help Group-Bank Linkage Programme in Nagaland: A Case Study of Peren, Kohima and Dimapur District of Nagaland. International Journal of Multidisciplinary Approach and Studies 1(6), 52-60.

Mishra, A.K., Langwangbe, K.T., 2014. Self-Help Groups, a model for Economic Growth in Nagaland.International Journal of Recent Research in Commerce Economics and Management 1(3), 89.

Ramachandran, T., Balakrishnan, S., 2008. Impact of SelfHelp Groups on Women's Empowerment: a Study in Kanyakumari District. Kurukshetra 57(2), 31-44.

Swain, R.B., Wallentin, F.Y., 2012. Factors Empowering Women in Indian Self-Help Groups Programs. International Review of Applied Economic 26(4), 425-444.

Young, K., 1993. Planning Development with Women: Making a World of Difference. London: Macmillan, 159. 